Scientia Militaria vol 40, no 3, 2012, pp.177-199. doi: 10.5787/40-3-1027

\section{From El Wak to Sidi Rezegh: The Union Defence Force's First Experience of Battle in East and North Africa, 1940-1941}

\section{Gustav Bentz}

\section{Abstract}

South Africa entered the Second World War on the side of Great Britain in September 1939 and, in spite of extensive changes and an increased budget, the Union Defence Force (UDF) found itself in a state of war on 7 September 1939 with a Permanent Force of only 5400 men with limited training and antiquated equipment. While Hitler's armies conquered Western Europe the Springboks prepared to go North and in spite of trepidations about the might of Mussolini's East African Empire the First South African Infantry Division set sail for East Africa in mid-July 1940. In five short months, Mussolini's East African Empire had been torn to shreds. Victorious in every major engagement, the South Africans embarked for Egypt in June 1941. Here they encountered similar logistical problems as were prevalent before they embarked for East Africa. With two divisions in the field and a third in training, UDF planners had a trying time marshalling enough motorised transport to enable the Springboks to keep pace with the increased mobility that was a hallmark of desert warfare. Expecting to build on their success over the Italians the South Africans confidently went into battle, but by November 1941, the $5^{\text {th }}$ South African Infantry Brigade was annihilated and the victors of East Africa badly mauled. Fighting lowmoraled Italian armies in the bush and mountains of Abyssinia was quite easy; beating the Germans in the desert would be a different story altogether.

- Captain Gustav Bentz is a lecturing assistant and MMil candidate in the Department of Military History, Faculty of Military Science, Stellenbosch University.
Keywords: South Africa, Second World War, UDF, first battles, Abyssinia, Libya

\section{Introduction}

With South Africa's economy showing an upward trend at the end of 1933, the UDF began a process of recovering from the financial and organisational restrictions imposed on it during the previous years of depression. Leading this recovery, in 1934, Oswald Pirow, Minister of Defence (1933-1939), committed himself to a yearly increase in the defence budget in order to enable the UDF to produce maximum military effectiveness and efficiency. When war was eventually declared on 7 September 1939, the principles of the Union's policy on defence rested on three pillars. The government committed itself to prevent and suppress internal unrest. Any military involvement in this regard would be directed against "native" uprisings and rebellions. The second area of focus was to provide military training to a section of the white male population of South Africa. This would serve, in the event of mobilisation, to have partially trained personnel ready for military service. ${ }^{1}$ The next focus area of the government's policy on defence was that of protection against an external threat. The possibility of an external invasion of the Union by a foreign power was deemed to be extremely unlikely ${ }^{2}$ and it was much more likely that the UDF would be called upon to react to large-scale instances of native violence in Southern Africa, as happened, in May 1935, when African mineworkers in Lusaka, Northern Rhodesia, went on strike to protest against increased taxes, imposed by the British Colonial Government. This strike was violently suppressed by the authorities and sensitised the South African Defence Council members to the possibility of large-scale native unrest.

Pirow thus envisioned a pure defensive force and through his five-year plans worked towards this goal. ${ }^{3}$ H.J. Martin and N.D. Orpen are instrumental in their discussion on the Union's preparedness for war in volumes two and seven of their South African Forces in World War Two series ${ }^{4}$ while various articles on the state of the UDF in the years before the war as well as the process of mobilising the Union's limited military might have also been published. ${ }^{5}$ The work done by J.J. Collyer ${ }^{6}$ on the First World War played an important part in determining the direction UDF planners embarked upon during the interwar years. 
More than a year would pass before the Springboks would have their baptism of fire. This period included mobilisation, equipping and training of a defence for offensive operations in East Africa. Smuts envisioned his men as fighting alongside their British allies throughout Africa and hoped that his countrymen would flock to the recruitment centres to answer the call for volunteers. The South Africa Defence Act, however, restricted service to Southern Africa, and it was for this reason that, on 29 March 1940, all serving members had the opportunity to undertake a new oath, binding then to service anywhere in Africa. ${ }^{7}$ The new oath was not as eagerly accepted as was anticipated, and several units lost as much as $50 \%$ of their personnel who declined to take the new oath. The loss of personnel resulting from the institution of this new oath did delay the process of mobilisation, but was overcome with a new and even more energetic recruitment process. ${ }^{8}$

When the Springboks were eventually let loose upon the waiting Italians at El Wak on, 15 December 1940, they did so after months of training and careful preparation. If the battle-hungry South Africans expected their first encounter in modern war against a fellow European nation to be a hard-fought affair they were to be sorely disappointed. The raid on El Wak was a textbook execution of a military operation where everything counted in the attacker's favour. Orpen $^{9}$ is once again the starting point for information on this battle. Had this action been fought over several days and had it included thousands of combatants, it might have warranted more than the mere nine pages Orpen dedicates to South Africa's first taste of conventional war. Other authors ${ }^{10}$ treat the battle almost as a footnote in the chapter on the East African campaign. For a greater understanding on how this action unfolded one should consult the war diaries of individual units that participated. ${ }^{11}$ This official record of the day's events can be easily supplemented by personal diaries and memoirs of men of the $1^{\text {st }}$ South African Brigade. ${ }^{12}$ Although the Springboks never suffered a defeat in the campaign there were occasions when the defenders resisted stoutly. Such instances were however rare and the South Africans who left for Egypt in June 1941 felt invincible and thought of themselves as battle-hardened veterans.

The aim of this article is to contrast some of the experiences of UDF troops during the East and North African campaigns with each other by means of focusing on their "first battles" in each of the theatres. The discussion will commence with a brief discussion of the Union's preparedness for war after which the Raid on El Wak in which the Springboks achieved their first overwhelming victory will be dealt with. The focus will then shift to North Africa where the UDF once more prepared for the coming campaign. In the North African campaign, the South Africans however had twice the number of men to supply and train, completely different terrain to master, and skills and drills to learn for a style of warfare in which they had no experience.

\section{Preparing for War}

In preparation for the coming conflict, South Africa's Minister of Defence Oswald Pirow envisioned the country's defence force dealing with native uprisings in Southern Africa and with defending the country's borders against foreign invasions. Pirow drew on the experience of experts in the field of conducting such "police actions", like General Paul von LettowVorbeck, who was acknowledged as the master of bush-fighting at the time. $^{13}$ The UDF, more specifically the army, would be trained along the lines of light raiding columns, capable of conducting operations in the Southern African bush. ${ }^{14}$ Mobility for such columns would be based on Pirow's brainchild, the "all-terrain" or "bush" carts. These were twowheeled carts, to be drawn by oxen or mules, and deemed to be much more suitable and cost-effective than motorised transport. ${ }^{15}$ The view regarding mechanisation, at the time, was that it should be undertaken with caution and only after careful consideration of its limitations as well as effectiveness. ${ }^{16}$

The ability of the country to supply a mechanised force with spare parts, oil and petrol seemed unlikely, especially when the area of operations is considered. ${ }^{17}$ Early trials with the "bush" carts proved quite promising. The idea was hailed as proving quite suitable for its intended purpose. It was reported that during exercises, these carts were exposed to heavier types of work than they would ever be called upon to do. ${ }^{18}$ It was considered that such means of transport would be of greater value to the forces in the field than mechanised transport. Two main reasons influenced the decision to proceed with the "bush" cart experiment. The first was the possibility that South Africa could supply sufficient numbers of mechanised transport to serve the needs of the defence force, both in time of peace and in war. For a 
country still recovering from economic hardships imposed by the Depression, achieving this simply did not seem possible.

The second motivation was that of reliability. It was questioned whether mechanised transport could negotiate the narrow tracks of subtropical Africa, much of which were either covered with mimosa thorns and fine dust that turned into almost impassable dust clouds when disturbed. In the rainy season, mechanised transport would get sucked up to its axles into mud. ${ }^{19}$ Pirow was convinced that mimicking the European style of fighting in Southern Africa or composing forces along the lines of the great armies of Europe would be useless. It is thus clear that the idea of mobile offensive operations have not manifested in most of the Union's military planners of the time. Concerning any possible seaborne invasion or threat, South Africa would have been protected by its extensive coastal defences, fortified harbours and the Royal Navy. It was further estimated that the UDF only needed to prepare to meet, on the field of battle, a force one third the size of the country's total forces. ${ }^{20}$ This strategy worked well in East Africa and upon conclusion of the campaign, the UDF men felt invincible.

\section{The Springboks move North}

On 27 November 1941, Italian delegates, representing the last pockets of resisting Italian troops in East Africa, surrendered what was left of Mussolini's East African empire to the East African Brigade Headquarters. This event effectively brought the fighting in East Africa to an end. For the men of $1^{\text {st }}$ South African Division, the long road to victory began on 24 July 1940 when they disembarked at Mombasa, Kenya. ${ }^{21}$

The brigades of the $1^{\text {st }}$ Division quickly adapted to this new style of warfare in this, their first modern war where mechanisation and aerial elements were added to the commander's arsenal. When the last troops of the division embarked at Massawa, on 12 June 1941, the regiments making up the brigades could add to their battle honours the names of El Wak, Combolcia, the Juba, Amba Alagi and East Africa 1940 -1941. In addition, the Springboks could lay claim to eliminating from this global conflict an impressive 236000 Italian combatants, 30 generals, 42 tanks and 403 guns. Certainly not a bad accomplishment given the fact that a secret report presented to the Minister of Defence in December 1939 estimated the Italian strength in East Africa to be close to $165000{ }^{22}$

To counter this Italian juggernaut, the Commonwealth could muster a mere 20000 infantry and 68 guns as stated by the South African Bureau of Information in 1941. The actual number of South Africans involved in the East African Campaign was 38 730, with a peak total of 43730 reached in April 1940. ${ }^{23}$ The UDF sustained 270 casualties during the campaign, 73 of which were fatal.

The battles of the East African campaign were in many cases mere dress rehearsals for future operations in North Africa. The forces used by the Springboks in their first battle were so slanted in favour of the attackers that the "Raid on El Wak" does not do much justice to the term "first battle". The men of $1^{\text {st }}$ South African Brigade arrived at Gilgil towards the end of July 1940 and commenced with routine duties which included the digging of trenches and air raid shelters, erection of tents and the completion of several unfinished bungalows. ${ }^{24}$ As in any other war, casualties were not only sustained on the battlefield but also in the mess halls, bungalows and ablution facilities. Initial skirmishes arose from diarrhoea, which caused a whole lot of dashing to the cover of the latrines in a desperate search for relief. Several men became seriously ill during the first few days and had to be put off duty. ${ }^{25}$ A further non-combat-related injury that would plague the men was "Habaswein Itch", "Wajir Clap" or "Buna Balls", ${ }^{26}$ which was a condition brought about by the high mineral content of the drinking water to be found in East Africa. Sufferers of this condition had an excruciating experience when trying to urinate as a result of sharp crystals of undissolvable mica and gypsum that formed in the urinary system. ${ }^{27}$

Training was continued as if the men were still in the Union and followed a "civil service" pattern, starting on Monday and ending on Friday while the weekends were to be spent as the men saw fit. ${ }^{28}$ Larger-scale brigade exercises were also conducted on a rotational basis with each regiment conducting offensive operations against another in defence. ${ }^{29}$ With several intensive field manoeuvres, route marches and evening lectures about a myriad of military aspects under the belt, the South Africans eventually crossed into the Northern Frontier District (NFD) on 16 September to reach Wajir two days later without any casualty or 
incident, ${ }^{30}$ much to the utter disappointment of some of the men. Rumours of Italian reconnaissance planes to the north were rife. The use of native tribes as irregular force (called Banda) by the Italians was some cause for concern, as the Banda were thought to be infiltrating from the north and likely to ambush any unlucky convoy that dared to venture to far into unsecured areas. ${ }^{31}$ The South Africans were confident that they would be able to deal with any threat posed by local natives since most of their previous training was focused on suppressing such local uprisings.

There was more than enough time for training, and to enable the different platoons to gain operational experience, a system of platoon and company rotation was implemented. This meant that men not on patrol spent their days digging defensive works, marching on compass bearings, conducting firing exercises, debussing from vehicles during mock ambushes and some night driving without lights. ${ }^{32}$

By December, the Springboks had seen their share of small skirmishes and ineffective Italian aerial bombardments. They were however eager to test themselves in a real battle and many felt that "we are all getting tired of doing nothing useful and even the most peaceable of us are longing for action”. ${ }^{33}$ The new chief in charge, Gen. Alan Cunningham, was equally eager to test his light tanks and armoured cars in a region of very thick bush and deep sand. Consequently, he planned a coordinated attack against five defended frontier posts controlled by the Italian enemy. ${ }^{34}$ The first set-piece battle by UDF troops in the Second World War was about to unfold.

\section{Raiding the Wells of the Gods ${ }^{35}$}

The focal point of Cunningham's attack was El Wak, one of many stone forts that marked the border between Italian- and British-controlled territories. From 10 to 12 December, $1^{\text {st }}$ South African Brigade commenced rehearsing for the coming battle. Everything about the coming confrontation was planned and rehearsed in minute detail. While still at Wajir, the Brigade rehearsed debussing from vehicles, movement through the bush on compass bearings, camouflaging vehicles and equipment as well as digging more trenches. On 12 December, the various officers commanding explained to their subordinates the plan which was to be followed by each platoon the next day. In turn, they received detailed instructions from their officers on their particular role in the upcoming action. With each man now knowing what would be expected of him, the Brigade set off toward their objective at eleven on the morning of 14 December. ${ }^{36}$ The plan called for the destruction of five separate enemy-held positions along the frontier by South African regiments grouped with various African contingents and supported by armoured cars and light tanks. On 16 December the attacks commenced. ${ }^{37}$

This type of warfare was unfamiliar to most European soldiers but the South Africans who have been training for this kind of fighting since their enlistment felt quite at home in the dense African bush. ${ }^{38}$ Anxious moments were however experienced when an enemy bomber passed overhead at a quarter past six on the morning of the day of the attack but the starting lines were reached in the course of the morning and the enemy sighted. ${ }^{39}$ The attacks followed similar patterns of advancing South Africans spasmodically engaged by Italian artillery. This unwarranted attention was then in turn answered by accurate counter-artillery fire while armoured cars and tanks thundered through the bush closely followed by charging infantry. ${ }^{40}$ The biggest concern for many of the attacking Springboks was that there would not be any enemy worth fighting or that the UDF men would simply walk right into the objective. ${ }^{41}$

The objective assigned to one of the attacking South African regiments, the Natal Carbineers, was held by a contingent of Abyssinian Regulars, supposedly crack Italian troops. ${ }^{42}$ They were believed to be trained in the use of machine guns and to have the support of three artillery batteries in the vicinity of El Wak. The defenders of El Buro Hachi were in fact conscripts and formed part of the $191^{\text {st }}$ Colonial Battalion that relieved the $73^{\text {rd }}$ Colonial Battalion at the beginning of December. Intelligence reports revealed that several desertions from the $73^{\text {rd }}$ Colonial Battalion have occurred as well as some cases of suicide. Discontent among the Banda were rife and morale in general was dangerously low. ${ }^{43}$

The Carbineers managed to bring their mortars much closer to the start line during the night and when the infantry broke through the bushes, 700 meters away from their objective, the value of such move was confirmed. ${ }^{44}$ An Italian field gun, which opened up on the advancing troops, was quickly silenced by South African mortar crews. Amidst the enemy's initial bursts 
of machine gun and random artillery fire, the Carbineers, chanting their Zulu war songs with fixed bayonets, charged at and routed the defenders. ${ }^{45}$ It was during the opening stages of the battle that the Carbineers suffered not only their first, but also the first UDF battle casualty of the war. The small field gun that initiated the action drew first blood as one of its shells landed among one of the mortar detachments, killing two and wounding two others. ${ }^{46}$ With the rest of the defenders fleeing to the north, the Carbineers secured the objective and continued to "liberate" the town and the dead of anything useful and interesting, which included watches, tents, officers' uniforms and beautifully decorated revolvers. ${ }^{47}$

The presence of the South African Air Force (SAAF) was a definite morale booster to the men on the ground. The ageing Hartbeest fighters of the SAAF managed to establish air superiority and kept the skies clear of enemy bombers or fighters. On the rare occasions that Italian planes ventured into South African airspace they were met by determined Springbok pilots and dealt with abruptly. ${ }^{48}$ In addition, the Army Cooperation Squadron dropped maps of enemy positions and assisted in guiding ground troops to various objectives. ${ }^{49}$ At day's end, the men of $1^{\text {st }}$ South African Brigade could proudly record in their diaries that "now we are all soldiers". 50

The battles that followed were set-piece affairs where outnumbered and demoralised Italian troops defended a static mountain position in the hope of delaying the advancing Union troops. The exception to this rule was during the battle of Keren where, although no South African troops were present, determined Italian resistance resulted in heavy British and Indian casualties. ${ }^{51}$ This style of warfare suited the South Africans who were used to infantry operations in the bush and mountainous areas. Valuable lessons were learnt during operations in East Africa, which would assist in the preparation for the campaign in North Africa. Military planners noted in particular that, as the campaign developed, enemy resistance changed from mere static defensive positions to deliberate counterattacks with artillery and tanks, whenever the latter was available. ${ }^{52}$

Planning for North African operations began on 10 April 1940 when Lieutenant General G.E. Brink (1889-1971) left by air for South Africa to confer with Prime Minister J.C. Smuts (1870-1950). It was during one of the many meetings with the Chief of General Staff, Lt. Gen. Sir Pierre van Ryneveld that Brink complained about the shortage of manpower and stressed the fact that South Africa could not maintain three full divisions in the field. At that stage, the $1^{\text {st }}$ South African Infantry Division was concluding its campaign in East Africa, the $2^{\text {nd }}$ South African Infantry Division was preparing to be deployed to North Africa and the $3^{\text {rd }}$ South African Infantry Division, 6000 strong, would remain in the Union, ready to provide reinforcements and guard the home front against subversive elements. On a request for home leave for his men, Brink was told that such a request would be at the discretion of the Middle East commander-in-chief (MEC). He was also informed that, since many of his guns were still in East Africa, he would have to rely on the British in Egypt for support. The most depressing news however was that 13000 vehicles were to be shipped from East Africa and allocated to the $2^{\text {nd }}$ South African Infantry Division. The $1^{\text {st }}$ South African Infantry Division would thus be without its full complement of transport as it entered the North African theatre with any request for replacement vehicles handled by MEC. ${ }^{53}$

\section{In the Land of the Pharaoh's}

Upon arrival in Egypt, the $1^{\text {st }}$ South African Division was allocated Mersah Matruh as its base area while the $2^{\text {nd }}$ South African Infantry Division was stationed at Mareopolis near Alexandria. It would be at Mersah Matruh that the $1^{\text {st }}$ South African Infantry Division, would for the first time since its formation in the Union have all three its brigades in one location. A troop train awaited the troops at Port Tewfik and after having been filled to the brim would start its long hot journey to Amariyah, ${ }^{54}$ a military encampment not far from Alexandria. The train would hardly have moved when a horde of fellaheen (agricultural labourers) would leap on board through the many doors and offer for sale a variety of goods. Chief among these would be small round tins containing a dark, smelly substance, which the troops were assured, was Spanish fly, guaranteed by the seller to arouse the passion of any and every woman of their choice. Where such commodities would be found on the front lines was hotly debated afterwards. ${ }^{55}$ The South Africans were not impressed with their first encounter with Egypt. They complained about the flies, fleas, dust, heat and dirty Arabs who they thought were the most unhygienic and filthy crowd of people to be found anywhere. ${ }^{56}$ 
Settling into the routine that desert life brought, namely "late rise, day off, washed clothes, guard"57 the South Africans could take stock of their situation and all the new things that Egypt had to offer. Leave to Cairo became part of everyday life. There a myriad of clubs opened for all ranks and colours. There were also many a first battle between the men from the Union and the British red caps tasked with keeping some semblance of order. To the victors of East Africa, the desert with its rocky plains and camel shrub appeared to be without advantage for attacker or defender. Having just mastered the bush and hills of East Africa, the South Africans were confronted with the reality that much of the lessons learnt fighting the Duke of Aosta's men would now benefit them very little. The most important change of all was that of opponents. In East Africa, the South Africans faced a largely demoralised and unmotivated enemy whose ranks were inflated by opportunistic tribesmen who at the first sign of defeat would melt away into the bush. The conscripted Italian civil servants who did take up arms had just as much to fear from the local population as from the South African troops. In contrast, the German Afrika Korps was much better organised, equipped, motivated and lead by officers with, at that stage in the desert war, unparalleled experience. ${ }^{58}$

\section{From the Coastline to the Front line}

It was in Egypt that the South Africans experienced their first, but by no means the last, determined air raid of the war. Gone were the days of pairs of Capronis lazily passing over South African positions and conducting halfhearted and inaccurate bombing runs. Air raids took place at night over the harbour at Alexandria where numbers of Royal Navy ships were moored. The air raids in East Africa usually commenced at dawn when the troops were supposed to be most vulnerable or at dusk when pursuit would be inevitable, but never at night. The Egyptian anti-aircraft guns fired in the general direction of the raiders, with a percentage of the shells aimed at the army camp at Amariyah. When this happened the troops had to take cover, and it was their first introduction to hostile fire as it was argued that certain members of the Egyptian army were not at all friendly toward the Allied troops. $^{59}$ Closer to the front line the troops discovered that the German weapon of choice for raining destruction from the air was the JU87 Stuka dive-bomber. It was as frightening as it was lethal. It carried one 500-lb bomb between its dangling undercarriage. Four smaller bombs were hung beneath the wide wings of the aircraft, and on one of its hanging legs was attached a siren actuated by a propeller whirring in the wind, giving off a piercing shriek with the intention of paralysing its victims with fear. The bombs were designed to detonate on contact with the stony desert floor with a deafening crack, sending jagged white hot steel splinters and sharp-edged broken stones flying almost horizontally through the air. ${ }^{60}$

At Mersa Matruh, the Springboks went to ground, or rather underground. The constant German air attacks necessitated the digging of bunkers and underground passages, ${ }^{61}$ many of which became quite elaborate. Describing his lodgings as a "porcupine's warren", one soldier wrote to his parents that they have two large rooms, a storeroom, kitchen and pantry, all underground. In his following letter, he informed his parents that they had improved their "termites nest" and added a large underground dining room with a floor of sandbags and a table in the centre. ${ }^{62}$ The presence of fleas and lice, however, forced many a Springbok to sleep above ground and only share the underground safety with its unwelcome inhabitants when an air raid was imminent. ${ }^{63}$

\section{Training for Desert Operations}

The Division, instead of receiving new motorised transport (MT), received the minimum number of old battered trucks. With insufficient MT available, the division resorted back to the laying of minefields and digging more defences in the Mersa Matruh area. ${ }^{64}$ For the time being, the sorely needed training in desert movement, night movement and navigation would have to be postponed. During the East African campaign, the South Africans drove in single file, often forced to do so by dense bush, and deployed on foot. What they now needed in the Western desert was to practice mass movement in the desert. With transport still lacking, the South Africans continued working on new defensive positions, gun emplacements, concrete pillboxes, clearing of tank ditches, laying of mines and the erection of wire, sometimes for up to twelve hours per day. ${ }^{65}$ It was this state of semi-unpreparedness that was to lead to the delay of the Crusader campaign and caused a rift between the South African field commanders and their British superiors. 
After repeated appeals by the division commander, suitable and desert-worthy vehicles began to arrive early October. The $1^{\text {st }}$ South African Division commenced its first lessons in desert training on 11 October 1941 in all earnest. General Brink demanded twenty-one days in which to bring the division up to a reasonable standard in desert warfare. This was however not to be, as the defensive work had to proceed, resulting in only individual brigade exercises. ${ }^{66}$ The men on the ground cared little for the politics of high command and were determined to master this new way of war in the shortest possible time. The slow movement through the Western Desert was intended so that the troops might be thoroughly acclimatised to desert conditions. This toughened them up and they soon became accustomed to the dust, sand and bumpy roads. Each section of thirteen men was carried in a five-ton Ford truck along with a sack of maize meal, a big bag of onions, a few boxes of bully beef and assorted items such as salt, tea, sugar, other foodstuffs and the perennial army biscuits. Water was rationed to one water bottle per man per day and this was pooled to be used for cooking and making tea.

It was in the nature of things that a brigade, composed of three thousand men, hundreds of trucks, dozens of 25-pounder guns and the quads which pulled them, with ammo limbers trailing behind, would be an ideal target for marauding Stukas dropping their bombs, aided by Messerschmitt fighters, something the South Africans did not experience in East Africa. Because of this and because of the open flat desert which gave no cover, vehicles had to maintain a reasonable distance between each other. When the Brigade was on the move, it occupied a great expanse of desert and raised a fair amount of dust. Armoured cars were the eyes and ears of the brigade and roamed at will along the edges of the column, keeping in radio contact with headquarters, which usually travelled in the centre of the column. Travelling speed was about 40 kilometres per hour, which could be substantially increased if some German tanks or armoured cars appeared through a haze of sand and dust determined to cause mischief. Exercises often took the form of attacks against an imaginary enemy, night patrols and group movements. ${ }^{67}$

\section{Operation Crusader}

As October changed into November few UDF commanders had any illusions regarding the battle readiness of the brigades. On 8 November, the two corps commanders General Godwin-Austin ( $13^{\text {th }}$ Corps) and General Norrie $\left(30^{\text {th }}\right.$ Corps) issued their operational orders to subordinate commanders. At this stage, the $2^{\text {nd }}$ South African Infantry Division was stuck at El-Alamein laying mines and preparing defences. The $1^{\text {st }}$ South African Infantry Division was still busy with its desert training with its $1^{\text {st }}$ Brigade having barely begun exercising in countering armoured attacks while the $5^{\text {th }}$ Brigade did not even progress past the battalion scheme exercises ${ }^{68}$ and would not be ready when General Sir Alan Cunningham's Operation Crusader commenced on 15 November. General C. Auchinleck, as commander-in-chief Middle East Command, wrote to Churchill expressing his severe disappointment at the state of readiness of the South Africans but defended his decision to postpone offensive operations by three days to allow the South African commanders time to carry out one last exercise. $^{69}$

In spite of securing three extra days, much to the dismay of his superiors, in which to train his men, Brink had to decide between sending his untrained men against the Germans or to have his division replaced by the $4^{\text {th }}$ Indian Division and become a national embarrassment. In true South African fashion, Brink chose to fight and the $1^{\text {st }}$ South African Infantry Division left its base at Mersa Matruh on 3, 4 and 5 November en route for their respective jump-off points for the battle to come. Determined to squeeze in as much training as possible, the South Africans conducted exercises while moving to their concentration areas near the border between Egypt and Libya. It was during these exercises, that it was discovered that according to the $8^{\text {th }}$ Army's supply plans, the brigades had to cover eight miles to the gallon of fuel. With the state the vehicles were in, tough terrain and leaking fuel cans, the $5^{\text {th }}$ South African Infantry Brigade could only manage four miles to the gallon. This resulted in the brigade running out of fuel halfway to the concentration area. ${ }^{70}$

Cunningham's aim with Crusader was to draw out the enemy armour in the Tobruk area and to eliminate it as fighting force. This would lead to the relief of the Tobruk garrison and, in all likelihood, the retreat of the Axis forces from Eastern Libya. The concept of the plans was based on splitting his force into three groups. The Northern group would isolate the enemy in 
the Sollum-Sidi Omar region. The centre force would be responsible for drawing away the enemy armour from the Northern group in the direction of the Southern group. The Southern group consisted of the $7^{\text {th }}$ British Armoured Division, $1^{\text {st }}$ South African Infantry Division and the $2^{\text {nd }}$ Guards Brigade with the task of seeking out enemy armoured formations, destroying them and relieving the besieged Tobruk garrison. In spite of the decision to split up the British tank forces and the concern of the infantry commanders at having to fight tanks, the allied forces crossed the Wire during the night of $17 / 18$ November $1941 .^{71}$

\section{Cunningham Courts Disaster}

With the lumbering mass of vehicles of the $8^{\text {th }}$ Army moving in a western direction into Libya, the general feeling was that no-one had a clear idea of what was happening or where they were going. ${ }^{72}$ The Division, on 18 and 19 November, followed in the tracks of the $7^{\text {th }}$ British Armoured Division, eagerly awaiting the conclusion of the armoured battle. On 19 November, in the afternoon, Brink received orders to dispatch $1^{\text {st }}$ South African Infantry Brigade to Gueret Hamza and the $5^{\text {th }}$ South African Infantry Brigade to El Cuasc. Moving into position, the $1^{\text {st }}$ South African Infantry Brigade was the target of a determined air attack which claimed 19 lives. $^{73}$ It was during this movement that the $22^{\text {nd }}$ British Armoured Brigade charged headlong into Italian defensive positions at Bir el Gubi.

This engagement, described by General Norrie as an encounter battle, carried out too enthusiastically against prepared positions, failed to dislodge the defenders. At day's end, fifty per cent of the brigade's tanks remained on the battlefield as either smouldering heaps or useless hunks of metal. ${ }^{74}$ This attack by untrained troops in their first action since arriving in the desert resulted in one of the three armoured groups, tasked with destroying the German armour, was unable to play its part without substantial reinforcements. It also meant that the $1^{\text {st }}$ South African Infantry Brigade's attack on Bir el Gubi on 20 November was called off but more critically was the fact that the South Africans were now without direct tank support. ${ }^{75}$

Having failed to lure the Germans into the trap, the Army Commander revised the original Crusader plan to focus on a drive on the Italian-held landing strip at Sidi Rezegh, in order to achieve at least one of the predetermined objectives. With the armour of the southern force tied up at Bir el Gubi, the northern force guarding the left flank of $13^{\text {th }}$ Corps, the only armour then available to execute Cunningham's plan of destruction was the lone $7^{\text {th }}$ Armoured Brigade. ${ }^{76}$ Brink was ordered to dispatch one of his brigades north in support of the attack on the airfield. With Brigadier Dan Pienaar's $1^{\text {st }}$ South African Infantry Brigade masking Bir el Gubi, the task of following the armour fell on Brigadier B.F. Armstrong's $5^{\text {th }}$ Brigade, which was instructed to take up a position on the third escarpment overlooking the landing strip. Darkness, however, descended upon the battlefield before the brigade could reach the escarpment and since it was not sufficiently trained in night movement, the brigade commander did not want to cover the last couple of miles in the dark. The $5^{\text {th }}$ South African Infantry Brigade consequently camped in a laager in the open desert with all intention of resuming its march at dawn on 21 November. ${ }^{77}$

In the afternoon of the same day, General Cruewell, commanding the German armour, obliged Cunningham by advancing on the $4^{\text {th }}$ Armoured Brigade at Gabr Saleh. Instead of relief, the news of the German movement created a panic at Army HQ. There were no longer three armoured brigades waiting for the enemy but only one. If the Germans managed to brush the British tanks aside, they would crush the remainder of $13^{\text {th }}$ Corps and cut off the rest of the army from its sources of supply in Egypt. Upon failing to eliminate the British forces in the east, the Germans, now two divisions strong after having linked up during the night, turned west in order to push the British off the landing strip and crush the $7^{\text {th }}$ British Armoured Brigade and its supporting elements. Cunningham, thinking the enemy was withdrawing ordered up his armour in pursuit. On 22 November, Rommel pushed the British off the airfield and beat back the attacks made by the $4^{\text {th }}$ and $2^{\text {nd }}$ Armoured Brigades respectively. ${ }^{78}$ With most of his armour destroyed or put out of action, Cunningham lost the decisive armoured battle that was crucial for Crusader's success. As survivors of the tank battle limped back in the direction of the Wire, the fate of the $5^{\text {th }}$ South African Infantry Brigade was sealed.

A counterattack by the Transvaal Scottish failed to regain the airfield and the $5^{\text {th }}$ South African Infantry Brigade attempted to dig in for the defence just south of point 178. At 07:30, the German armour began their advance south from Sidi Rezegh. In spite of having been observed by South 
African armoured cars, the German movement proceeded unopposed. Attempts at defending the perimeter commenced as soon as what was left of the echelon vehicles closed up on the Brigade HQ. On the periphery, were the infantry, the artillery behind them and Brigade HQ in the centre. The infantry dug themselves in - at least they tried to do so. The ground was hard shale, extremely difficult to penetrate with pick and shovel. The extremely rocky ground prevented effective entrenching and resulted in slit trenches of only inches deep, leaving the troops partially exposed.

The Brigade's anti-tank guns remained on their portees in order to be easily deployed as the situation demanded. Armstrong deployed what antitank weapons he possessed along the four sectors of his defensive box and included 46 25-pounder artillery pieces, 2 18-pounder anti-tank guns and 26 2-pounder anti-tank guns. In addition, he could call on the limited support of a few of the surviving tanks of the previous days' tank battle. ${ }^{79}$ During the night of 22 November, strong German armoured elements moved south in the direction of the yet undiscovered South African brigade. At 07:30 the next morning, the static South African units were spotted and the German commander, on his own initiative, ordered his force to turn west and engage the enemy. ${ }^{80}$

\section{Totensonntag: "Sunday of the Dead"}

German artillery began a steady bombardment of the brigade positions as the first shells came over with an unearthly scream and burst within the perimeter. They were loaded with steel balls which, when released from their steel casing by the deafening explosion, buzzed through the air like a swarm of angry bees. The South African artillery answered and the gunners could be seen through the rising clouds of dust, stripped to the waist in the heat of battle, firing their 25-pounder guns over open sights as if their very lives depended on it, as indeed it did. Through the thickening clouds of dust enemy tanks could be seen milling around on the edge of the defensive box. Behind the tanks were lorried infantry, waiting for the moment when they could debus and clear up the objective. As the German tanks penetrated the South African defences from the south and begin to engage the infantry battalions on the perimeter, organised resistance came to an end. ${ }^{81}$ The Germans wheeled west and rampaged through the $5^{\text {th }}$ Brigade's B echelon vehicles and other transport vehicles before disengaging to the southwest in order to regroup and prepare for another attack later in the afternoon.

Groups of men began to make off in their vehicles in an attempt to reach safety, but some pockets of resistance still existed. To combat the marauding tanks, the infantrymen had sticky bombs which were small spheres of glass-encased adhesive with an explosive charge in the centre. It was almost the size of a football. To detonate it one would pull out a wire clip to release the metal casing, then holding it by its handle, swing it against the side of the tank about to be destroyed. The glass would then shatter with the explosive sticking to the tank before the explosive charge would blast its way inward, killing all inside and destroying the tank. In addition to this lethal weapon, was a bottle filled with ordinary petrol, the so-called Molotov Cocktail. It would simply be flung at the tank and if it breaks it heats the tank up to such a degree that the crew gets out as fast as they can, ready to surrender. ${ }^{82}$ At 15 51, Brink received an urgent message requesting him to do anything that can be done to assist the $5^{\text {th }}$ South African Infantry Brigade $^{83}$

After two days at Bir el Gubi, $1^{\text {st }}$ South African Infantry Brigade was instructed to move north to Sidi Rezegh to assist the $5^{\text {th }}$ South African Infantry Brigade who was being attacked by overwhelming German forces. At 0600 on 23 November, Pienaar's men began to move north, and by 0930 found their way blocked by enemy infantry and tanks. ${ }^{84}$ With little more than a mile separating the $1^{\text {st }}$ South African Infantry Brigade from the outlying elements of the besieged $5^{\text {th }}$ South African Infantry Brigade, Brink sent the following message to Armstrong: "Ons is naby en ons kom. Hou vas., 85

Coming up to the ridge late on Sunday afternoon, the brigade moved forward in extended order. It was spread over a wide expanse of desert: infantry in trucks, artillery quads pulling 25-pounder field guns, and armoured cars on the outskirts keeping an eye out for the enemy. On the right was a rise in the ground, hardly a hill or even a hillock. It was high enough to hide from their view a large enemy force moving around the southern flank of the $5^{\text {th }}$ Brigade. The armoured cars gave first warning of the attack, coming into the moving brigade, sounding the alarm. ${ }^{86}$ With the head of the column subjected to heavy shellfire, the Springboks pulled back 
three miles and began preparing defensive positions. ${ }^{87}$ As a result of having to leave one infantry battalion behind at Bir el Gubi, Pienaar did not feel strong enough to conduct an attack without incurring serious casualties and decided instead to shell the enemy south of $5^{\text {th }}$ South African Infantry Brigade.

Radio communications with $5^{\text {th }}$ South African Infantry Brigade ended abruptly at 1555 and were never again restored. As day turned into night, it became apparent that the brigade had been annihilated. A few survivors who had escaped the killing, managed to reach safety in a shocked condition. They were fed and given blankets to protect them against the cold winter night. Of the 5800 men who went into battle, 2964 were listed as either dead, wounded or captured in this, the Union's first battle of the Desert War. ${ }^{88}$ In his dispatches to London, Auchinleck explained that, in spite of gallant resistance by the $5^{\text {th }}$ South African Infantry Brigade, the German attack was well conceived and executed resulting in the practical destruction of the South African force. ${ }^{89}$

At 02:00 on 24 November, Pienaar's brigade was ordered to fall back to Bir Taieb el Besem and to dig in. ${ }^{90}$ At dawn, they left a battlefield littered with burnt-out vehicles strewn over the desert along with smashed equipment and other debris. It was here that they were attacked by Italian armour, on 25 November, and would have suffered the same fate as the $5^{\text {th }}$ South African Infantry Brigade, had they not been rescued by the $4^{\text {th }}$ Armoured Brigade. ${ }^{91}$

\section{Aftermath}

As Rommel pursued the British eastward, he had to contend with the fact that Tobruk remained in allied hands and a serious threat to his lines of communications and supply. This and the coming up of British reinforcements from Egypt, including the $2^{\text {nd }}$ South African Infantry Division, coupled to the deteriorating system of replenishment by air and sea lead to a general German withdrawal from Cyrenaica on 8 December $1941 .^{92}$ There then followed about three weeks of German withdrawal followed by allied pursuit, until Rommel reached Gazala and once more offered battle. $^{93}$
In the days that followed the disaster in the desert, there was a pressing need to determine the cause and to prevent it from happening again. Some blame was even levelled at $1^{\text {st }}$ South African Infantry Brigade's commander, General Pienaar, when it was whispered that he did not want to risk the lives of his own men by rushing to the aid of the surrounded $5^{\text {th }}$ South African Infantry Brigade. The fact that he did not wish his men to die needlessly is supported by many of his subordinates who wrote in their memoirs and diaries of the love the men had for their general who wanted to ensure all his "boys" returned home safe. Pienaar's thinking might have been influenced by the high value placed on the lives of white troops during the past conflicts in Southern Africa.

Speculation soon gave way to practical solutions and Brink pointed out, again, that armoured brigades with necessary support groups would be much more practical than the two infantry divisions then in North Africa, and the idea of creating a South African Armoured Division began taking form. He reached this conclusion, while in Egypt in June 1941, by studying operations Brevity and Battleaxe, both of which failed, and he stressed that the task of the infantryman was to follow in the wake of armoured spearheads. Their role was to hold ground after the enemy armour had been neutralised. Such ground could then only be held when the infantry were properly dug in and protected by mines, wire and tanks capable of counterattacking. He wrote to Smuts that it would be futile to send infantry against armour or organised defensive positions such as might be encountered in North Africa. Brink was to be proved right six months later about the vulnerability of the South African brigades. In addition to more armour in the South African arsenal, it was acknowledged that air power was indispensable to winning the war and more specifically surviving on the battlefield. ${ }^{94}$ Where the Springboks ruled the skies in East Africa, the tables were turned during the Crusader operation thus denying the allied forces freedom of movement.

The tactics which were taught in South Africa for twenty years were based on the lessons learnt during the West and East African campaigns of the previous war. Those lessons served the Springboks well in Abyssinia but not in a type of country for which the South Africans have had almost no previous training and where they faced an enemy better equipped and better armed. $^{95}$ 
Department of Defence Archives (hereafter DOD Archives). Defence Policy of the Union. Diverse Group 1 , Box 10

DOD Archives. Minister's outline of Defence Policy, Diverse Group 1, Box 10.

$\mathrm{J}$ Ellis. "Oswald Pirow's five-year plan for the reorganisation of the Union Defence Force, 1933-1939". Scientia Militaria 30/2. 2000.

4 HJ Martin \& ND Orpen. South Africa at war: Military and industrial organization and operations in connection with the conduct of the war, 1939organization and operations in connection with the conduct of the war, 1939Volume 1: East African and Abyssinian campaigns. Cape Town: Purnell, 1968.

5 These include: A Wessels. "The first two years of war: The development of the Union Defence Forces (UDF), September 1939 to September 1941”. Military History Journal 11/5. June 2000. 165; J van Wyk. "Die Unie Verdedigingsmagte op die vooraand van die Tweede Wereldoorlog, 1934-1939”. Militaria 6/4. 1976; GE Visser. "Anglo-South African relations and the Erebus Scheme, 1936-1939". Scientia Militaria 35/1. 2007. 74; IJ van der Waag. "The Union Defence Force between the two world wars, 1919-1939". Scientia Militaria 30/2. 2000. 210.

6 JJ Collyer. The South Africans with General Smuts in German East Africa. Government Printers, West Africa. Pretoria: Government Printers, 1937.

7 Orpen op. cit., p. 7.

DOD Archives Library, E Millin, History of organisation and training of infantry and armour, Part 1, 8.

9 Orpen op. cit.

C Birkby. Springbok victory. Johannesburg: Libertas, 1941; E Rosenthal. The fall of Italian East Africa. London: Hutchinson, 1942; AF Hattersley. Carbineer. Aldershot: Gale and Polden, 1950.

11 DOD Archives, War Diaries Box 220, July 1940 - December 1940, 1 - 14 December.

12 J Hurley. Diary, 14 - 20 December 1940, Natal Carbineer's Archive; Interview with B Buckley, 18 September 2008, Pietermaritzburg; HG Symons. Diary, Natal Carbineers Archive Centre; D Stainbank to his parents, 19 December 1940, Stainbank Collection, Natal Carbineers Archive Cere.

13 O Pirow. James Barry Munnik Hertzog. Cape Town: Howard Timmins, 1948, 219.

14 Martin \& Orpen op. cit., p. 18.

15 Report by Lt. Col. HD Klopper on an exercise with Bush Carts late in 1939. DOD Archives, Experimental work, local manufacture, carts AT, Director Technical Service, Box 35

Collyer, The South Africans with General Smuts ... op. cit., p. 275. Collyer, The campaign in German South West Africa op. cit., p. 170.

Report by Lt. Col. HD Klopper op. cit.

Collyer, The South Africans with General Smuts op. cit., pp. 270-275.

Martin \& Orpen op. cit., p. 15.

21 Orpen, East African and Abyssinian campaigns op. cit., pp. 315-328.

22 DOD Archives, Pamphlet section, Box 59. Appreciation of the East African situation from the point of view of the Chief of the General Staff for the information of the Minister of Defence, December 1939, 2.
Orpen, East African and Abyssinian campaigns op. cit., p. 351.

J Hurley. Memoirs. Natal Carbineer's Archive, 27.

PCM Francis. Carbineer: Travels in Darkest Africa. Pietermaritzburg: Natal Carbineer trust, 1990, 95.

27 G Hanley. Warriors and strangers. New York: Hamish Hamilton, 1988, 218.

28 M Coghlan. Pro Patria. Pietermaritzburg: Natal Carbineers Trust, 2000, 30.

DOD Archives, War Diaries Box 220, July 1940 - December 1940, August, Appendix 3.

DOD Archives, War Diaries Box 220, July 1940 - December 1940, 16 September.

31 Hattersley op. cit., p. 65.

DOD Archives, War Diaries Box 220, July 1940 - December 1940, 20-30 September.

J Hurley. Diary, 10 November 1940, Natal Carbineer's Archive.

Hattersley op. cit., p. 68

Translation of El Wak.

DOD Archives, War Diaries Box 220, July 1940 - December 1940, 1-14 December.

37 Birkby, Springbok victory op. cit., pp. 95-98.

38 Rosenthal op. cit., p. 26

DOD Archives, War Diaries Box 220, July 1940 - December 1940, 16 December.

Birkby, Springbok victory op. cit., pp. 98-102.

J Hurley. Diary, 14 - 20 December 1940, Natal Carbineer’s Archive.

${ }^{42}$ Coghlan op. cit., p. 31.

DOD Archives, War Diaries Box 204, Intelligence Summary No. 11 for December 1940

44 Birkby, Springbok victory op. cit., pp. 100-101.

DOD Archives, War Diaries Box 220, July 1940 - December 1940, 16 December.

HG Symons. Diary, Natal Carbineers Archive Centre, 37.

47 D Stainbank to his parents op. cit.

48 Birkby, Springbok victory op. cit., p. 103.

49 Orpen, East African and Abyssinian campaigns op. cit., p. 351.

AD McDonald to Dr Fisher, 20 December 1940, AD McDonald Collection, Natal Carbineers Archive Centre.

51 Orpen, East African and Abyssinian campaigns op. cit., p. 237.

DOD Archives, War Diaries, Box 299, Lessons of the campaign in East Africa, 19 June 1941.

53 Birkby, Uncle George ... op. cit., pp. 156-157.

MS Coghlan. Shrapnel, sand and Stukas: The Carbineers in the Western Desert, 1941-1942. Pietermaritzburg: 1992, 3.

55 J Holland. Memories of the Middle East: June 1941 to April 1943. Natal Carbineers Archive: Privately Papers, 22.

56 Birkby, Uncle George ... op. cit., p. 171

${ }_{57}$ Birkby, Uncle George ... op. cit, p. 
Agar-Hamilton \& Turner op. cit, p. 80

Holland op. cit., p. 22.

Ibid., p. 24.

61 PCA Francis Collection, Natal Carbineers Archive.

62 HG Symmons, Letters to his parents 2 and 4 July 1941, Natal Carbineers

Archive.
Coghlan, Shrapnel op. cit., p. 3.

EP Hartshorn. Avenge Tobruk. Cape Town: Purnell, 1960, 78

Agar-Hamilton \& Turner op. cit., p. 88.

Ibid., p. 89.

PCA Francis Collection, Natal Carbineers Archive

Agar-Hamilton \& Turner op. cit., p. 89.

J Connel. Auchinleck. London: Cassel, 1959, 330-331.

Agar-Hamilton \& Turner op. cit., pp. 119-120.

Ibid., pp. 62-63.

A Moorhead. The Desert War: The North African campaign, 1940/1943. London: Hamish Hamilton, 1965, p. 91.

Birkby, Uncle George ... op. cit., pp. 156-157.

Agar-Hamilton \& Turner op. cit., pp. 62-63.

Agar-Hamilton \& Turner op. cit., pp. 62-63.

Agar-Hamilton \& Turner op. cit., p. 139

Ibid., p. 170

C Barnett. The desert generals. London: Cassel, 1960, 97.

Agar-Hamilton \& Turner op. cit., pp. 239-245.

BI Gudmundsson. Inside the Afrika Korps: The Crusader Battles, 1941-1942. London: Greenhill Books, 1999, 86-87.

Agar-Hamilton \& Turner op. cit., pp. 261-262.

Holland op. cit., p. 25.

Agar-Hamilton \& Turner op. cit., p. 275

Birkby, Uncle George ... op. cit, p. 220 .

Translated: We are close and we are coming. Hold on.

Holland op cit. 27.

Agar-Hamilton \& Turner op. cit., pp. 240-241.

Birkby, Uncle George ... op. cit., p. 244.

89 B Connel. Auchinleck. London: Cassel, 1959, 354-355.

J Connel. Auchinleck. London: Cassel, 1959

Barnett op. cit., p. 113.

Agar-Hamilton \& Turner op. cit., p. 466

Barnett op. cit., p. 121.

LP Locner. What about Germany. London: Hodder and Stoughton, 1943, 124

Birkby, Uncle George ... op. cit., p. 165. 